\title{
Banding Pattern and Fibrillogenesis of Ceratotrichia in Shark Fins
}

\author{
NORMAN E. KEMP \\ Division of Biological Sciences, Department of Experimental Biology, The University of \\ Michigan, Ann Arbor, Michigan 48109
}

\begin{abstract}
Study by light microscopy, scanning electron microscopy and transmission electron microscopy of the distribution, structure and growth of ceratotrichia in the anterodorsal fin of a lemon shark, Negaprion brevirostris, and in the tailfin of a nurse shark, Ginglymostoma cirratum, shows that the ceratotrichia are large collagen fibers which develop in bilateral rows within the dermis. Surrounding each ceratotrichium is a layer of peritrichial fibroblasts containing secretory vesicles, which appear to be the source of matrix constituents. The peritrichial matrix contains bundles of fine, unbanded collagen fibrils as well as larger, banded fibrils like those in the matrix of ordinary connective tissue. The structure of the peritrichial fibroblasts and of the subjacent peritrichial matrix is the same as that of the fibroblasts and matrix of the conventional connective tissue throughout the fin dermis. Ceratotrichia grow by apposition of collagen fibrils from the peritrichial matrix. In cross section the ceratotrichia appear layered, evidently because of close packing of constituent fibrils in lamellae. In longitudinal section the ceratotrichia exhibit the conventional $a, b, c, d$ and $e$ bands of collagen. The $e$ bands show two distinct subbands, and the $b$ bands three subbands. Periodicity of the banding pattern is approximately $640 \AA$ like that of conventional collagen fibrils.
\end{abstract}

Beyond their endoskeletal fin rays the fins of sharks are supported bilaterally by large dermal fibers called ceratotrichia (Goodrich, '04). It is clear that these fibers are homologous with the fibrous rays called actinotrichia, which are localized at the distal ends of bony rays in teleosts and also within the adipose fins of salmonids, siluroids, characins, synodontids and certain other fish (Brohl, '09; Garrault, '36; Bear, '52; Fitton Jackson, '62, '68; Kemp and Park, '70; Bouvet, '74; Géraudie, '77). It is equally clear that ceratotrichia and actinotrichia are members of the collagen class of scleroproteins (Bear, '52; Ysuchiya and Nomura, '53; Gross and Dumsha, '58; Gross, Dumsha and Glazer, '58; Sastry and Ramachandran, '65; Kimura and Kubota, '66; Dubey, '67).

The name elastoidin was given to the protein of shark fibers by Krukenberg (1886) because it had properties he considered intermediate between those of collagen and elastin. He found that elastoidin fibers, unlike mammalian collagen, contained a significant amount of sulfur and did not yield gelatin when boiled with water. Unlike elastin, the elastoidin fibers were not digested by pancreatic trypsin. Elastoidin fibers (ceratrotrichia) vary with the size of a shark. They may be up to $30 \mathrm{~cm}$ long and several millimeters wide in large sharks (Schmidt, '24; Fauré-Fremiet, '36a,b; Damodaran et al., '56). They are shiny and transparent, and may be yellowish or brownish in contrast to the white ordinary connective tissue surrounding them. They are spindle-shaped, tapering to fine points at either end. Their surfaces show longitudinal striations. Cross sections show peripheral grooves and layers of concentric lamellae.

Evidence from X-ray diffraction, chemical analysis and electron microscopy has established the collagenous nature of ceratotrichia. They yield wide-angle or low-angle diffraction patterns characteristic of collagen (Champetier and Fauré-Fremiet, '37; Bear, '52; McGavin, '62). Engeland and Bastian ('38) identified glycine, alanine, serine and hydroxyproline in an acid hydrolysate of elas- 
toidin fibers. An amino acid analysis by Damodaran et al. ('56) showed that these fibers had a hydroxyproline content similar to that of collagen from teleost fishes; however, they differed from other collagens in containing $0.35 \%$ cystine and a relatively high amount of tyrosine $(7.15 \%)$. Gross and Dumsha ('58) found that elastoidin yielded a water-soluble gelatin on autoclaving, plus a water-insoluble residue rich in tyrosine. They concluded that elastoidin is a two-component mixture composed of collagen and $14-26 \%$ of a non-collagenous protein. They also reported that elastoidin fibrils contained $0.77 \%$ carbohydrate. Kimura and Kubota ('66) have reported that an acid soluble fraction of elastoidin fibers contained $45 \%$ typical collagen and $55 \%$ non-collagenous protein. In their view the latter protein probably serves to bind collagen fibrils closely together and thereby contributes to the reduced solubility and higher thermostability of elastoidin as compared with ordinary collagen. Tyrosine derivatives in the non-collagenous protein may participate in cross-linking (Kimura and Kubota, '68, '69). Sastry and Ramachandran ('65) separated three protein fractions from elastoidin fibers of the tiger shark and of an unidentified shark.

Electron microscopy of isolated fragments of elastoidin fibers (Bear, '52; Damodaran et al., '56; Gross et al., '58; Piez and Gross, '59), of reconstituted fibers (Kimura and Kubota, '66), and of thin sections (McGavin, '62; McGavin and Pyper, '64; Kemp and Susko, '71) has confirmed that elastoidin is crossbanded with the periodicity of collagen. This paper describes details of the banding pattern in sectioned shark ceratotrichia and compares fibrillogenesis in these fibers and in conventional collagen fibrils of the fin.

\section{MATERIALS AND METHODS}

A wedge of tissue containing the distal tips of ceratotrichia was excised from the tip of the tailfin of a live nurse shark, Ginglymostoma cirratum, approximately $45 \mathrm{~cm}$ in length, provided for this purpose by Doctor Perry M. Gilbert during a visit with him at the Mote Marine Laboratory, Sarasota, Florida. In addition, blocks of tissue about 2 $\mathrm{mm}$ thick were excised from the margin of the leading edge of the anterodorsal fin of a small (ca. $40 \mathrm{~cm}$ ) lemon shark, Negaprion brevirostris, by Doctor I. Kaufman Arenberg, who obtained the tissue while he was engaged in a research project at the Lerner Marine Laboratory, Bimini, Bahamas. Nurse shark tissue for light microscopy was fixed in Bouin's fixative, and for electron microscopy in $6.25 \%$ glutaraldehyde buffered with $0.1 \mathrm{M}$ phosphate buffer at pH 7.4. Lemon shark fin tissue was fixed in 5\% glutaraldehyde in shark phosphate buffer (Long et al., '68) at pH 7.4. After transportation to Ann Arbor, Michigan, fin samples in glutaraldehyde were stored in a refrigerator for variable periods up to four years.

Nurse shark tissue for light microscopy was dehydrated with ethanol, cleared in amyl acetate, embedded in paraffin, sectioned with a Spencer rotary microtome, and stained with hematoxylin and eosin. Photomicrographs were taken on 4- $\times$ 5-inch Kodak Contrast Process Ortho film mounted in a Spencer camera. For scanning electron microscopy a glutaraldehyde-fixed block from the lemon shark fin was sectioned with a razor blade. The smooth-surfaced, thick section thus obtained was washed in water, dehydrated in ethanol and air-dried. It was then mounted on an aluminum stub with Duco cement and gold-coated. Scanning electron micrographs were taken with Polaroid Type $55 \mathrm{P} / \mathrm{N} 4-\times 5$ inch film on a JEOL scanning electron microscope, model JSM-U3, operating at $15 \mathrm{kv}$. Glutaraldehyde-fixed tissue for transmission electron microscopy was washed in $0.1 \mathrm{M}$ phosphate buffer, post-fixed for two hours in cold

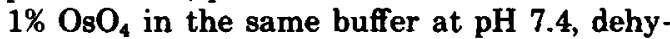
drated with ethanol, cleared with propylene oxide, and embedded in Epon 812. Blocks were oriented for cross or longitudinal sectioning of ceratotrichia, and thin sections were cut with a Dupont diamond knife mounted on an LKB Ultrotome. Sections were mounted on 200 mesh copper grids and stained with uranyl acetate and lead citrate. Electron microscopy was performed with an RCA EMU-3E electron microscope operating at $50 \mathrm{kv}$.

\section{RESULTS \\ General histology of fin tissue}

Cross sections from the margin of the anterodorsal fin of Negaprion brevirostris (figs. 1,2 ) or the tip of the tailfin of Ginglymostoma cirratum (figs. 3,4 ) show a bilateral disposition of ceratotrichia within the dermis. At the levels of section the lemon shark fin had several rows of ceratotrichia on either side of the central zone of ordinary connective tissue, whereas the nurse shark ceratotrichia were only in single rows. The ceratotrichia vary in 
size, measuring up to diameters of $200 \mu$ and $60 \mu$ in these specimens of lemon shark and nurse shark respectively.

The interior of the fin between the rows of ceratotrichia, as well as the outer portions of dermis between ceratrotrichia and epidermis, is composed of ordinary connective tissue consisting of fibroblasts and a collagenous matrix (figs. 1-4). Fibroblasts around the ceratotrichia form a flattened peritrichial layer (fig. 4). Placoid scales are embedded in the dermis and protrude through the epidermis (figs. $1,3)$.

\section{Structure of ceratotrichia and surrounding connective tissue}

\section{Banding patterns}

The banding patterns of ceratrotrichia and of conventional collagen fibrils in the tailfin of Ginglymostoma are illustrated in figures 5 and 6. In both fibrillar types the major periodicity is the same, approximately $640 \AA$, but staining characteristics of subbands appear to differ slightly. The most heavily stained bands are the $a$ bands, classified according to Hodge's ('67) terminology. In ceratotrichia (fig. 5), these bands are sharply distinct, whereas in the conventional fibrils (fig. 6) the $a$ bands are obscured by heavy staining on either side of them. Next in prominence of staining are the $d$ bands, about 0.4 of the distance from one $a$ band to the next. Two well defined $e$ bands are localized between $a$ and $d$ bands. On the opposite side of the $d$ band, within an electron-lucent zone is the narrow $c$ band. Close to the $a$ band on the side opposite the $e$ bands are three $b$ subbands.

Sections of conventional collagen fibrils adjoin the ceratotrichium (fig. 5). These fibrils vary in size and contain varying numbers of protofibrils. Electron-lucent matrix surrounding individual collagen fibrils is undoubtedly rich in proteoglycans and tropocollagen molecules. Although the ceratotrichium is cut longitudinally and the small collagen fibrils chiefly across in figure 5 , it looks as though fibrils in direct contact with the ceratotrichium are fusing with it. There is sufficient space between fibrils contacting the ceratotrichium, however, so that carbohydrate, tropocollagen or non-collagenous protein molecules might also bind to it and contribute to its growth. As new units join the ceratotrichium, interfibrillar space disappears and the fiber acquires its characteristic banding pattern.
Conventional collagen fibrils from the interior connective tissue at some distance from a ceratotrichium are illustrated in figure 6 . Fibrils run in bundles within which the constituent fibrils are approximately parallel to one another. It is noteworthy, however, that different fibrils within the same bundle may have opposing anisometry. In some, bands $a$ to $e$ are oriented toward one end of the fibril, whereas in others the bands are in the opposite polarity (fig. 6). Within ceratotrichia, on the other hand, the bands always are in the same polarity throughout the width of the fiber. Conventional fibers may grow to some extent through fusion of smaller fibrils, as indicated by points of bifurcation (fig. 6), but they tend to remain separate from surrounding fibrils within the non-collagenous matrix surrounding them.

\section{Fibrillogenesis}

Both conventional collagen fibrils and ceratotrichia are products of fibroblasts. Although the fibroblasts are dispersed through. out ordinary connective tissue, they surround the ceratotrichia in a peritrichial layer. Between peritrichial fibroblasts and the edge of a ceratotrichium is an assembly zone where collagen fibrils polymerize (figs. 7-12). Figure 7 illustrates a peritrichial fibroblast with its zone of assembly and adjacent ceratotrichium on one side, and a region of polymerization of ordinary collagen fibrils on the opposite side. The earliest fibrils which develop in the assembly zone beside a ceratotrich are clustered in electron-dense bundles (figs. 7, 8, 10, 12). At this stage they are about $100 \AA$ in diameter and unbanded. As they reach a diameter of about $200 \AA$, banding becomes evident. Fibrils may be oriented in various directions relative to the longitudinal axis of a ceratotrichium; thus they may be cut in cross section (figs. 8, 11) or in longitudinal section (figs. 9, 10, 12) alongside a ceratotrichium.

The peripheral cytoplasm of fibroblasts contains many spherical vesicles. Probably they contain tropocollagen and other constituents of the matrix to be secreted extracellularly. With respect to these vesicles, there is no apparent difference in the morphology of peritrichial fibroblasts (figs. $7,11,12$ ) and of fibroblasts of ordinary connective tissue (figs. 13, 14).

A striking distinction between ceratotrichia and conventional collagen fibrils is the elimination of extrafibrillar matrix in the 
former. As narrow collagen fibrils become apposed to the surface of a ceratotrichium (figs. $9,10,12$ ), the electron-lucent matrix between them is eliminated. There is no evidence that components of the extrafibrillar matrix are preferentially excluded from the growing ceratotrichia; nor is there visible evidence that any unique component not found in ordinary connective tissue contributes to polymerization of the ceratotrichia. Electron microscopy has not thus far revealed the localization of any carbohydrates or non-collagenous proteins which might be intercalated between collagen fibrils as they become bound to the surface of developing ceratotrichia.

\section{DISCUSSION}

Fish fins develop as outgrowths of the body wall and in their distal portions are essential. ly folds of skin. Within the dermal component fibroblasts are the principal cell type, and collagen is the principal protein of the connective tissue matrix. In elastoidin approximately $80 \%$ of the protein is collagen, the remainder being non-collagenous protein rich in tyrosine (Kimura and Kubota, '68). Shark fin soup, which contains the fibrous ceratotrichia (Ysuchiya and Nomura, '53) is principally a collagenous suspensoid. What regulates whether collagen in the shark's fin will polym. erize in the form of conventional collagen fibrils or in the form of the much larger ceratotrichia?

It is well known that collagen can repolymerize from solution in vitro into fibrils of various types (unbanded, native type, seg. ment long-spacing, fibrous long-spacing) or into membranes, depending on the environmental conditions during fibrillogenesis (Gross et al., '55; Olsen, '67). Recent studies on intermolecular crosslinking of collagen molecules have implicated aldimine double bonds, or the more stable reduced aldimine bonds, between lysine and hydroxylysine residues of adjacent molecules as important in fibrillar stability (Bailey et al., '74; Pinto and Bentley, 74). Intermolecular covalent bonding between collagen subunits undoubtedly accounts partly for collagen fibrillogenesis, and hence for polymerization of ceratotrichia.

Proteoglycans and non-collagenous proteins must also be considered as participants in the binding of collagen into fibrils and fibers. Gross and Dumsha ('58) considered it an open question whether the carbohydrate moiety of connective tissue "is an intrinsic part of the collagen molecule or became bonded to the fibril as an innocent bystander." Galactosyl and glucosyl-galactosyl residues may be crosslinked with polymerized collagen, and carbohydrates may show progressive increase in binding to collagen with increasing age (Bailey et al., '74). Bouteille and Pease ('71) have shown that collagen from rat tail tendon apparently has a carbohydrate moiety tightly bound to the protein helix. Fitton Jackson ('68) has observed that the glycosaminoglycans of the ground substance probably influence polymerization of collagen. Shark elastoidin fibers analyzed by Gross et al. ('58) contained $0.03 \%, 0.7 \%$ and $0.07 \%$ hexose amine, hexose and pentose respectively. Values for these same sugars were nearly the same for carp corium gelatin and for purified cow collagen in their study. Percentages of sugars were significantly greater, however, in extracts from entire corium of carp, cow or calf. Their data indicate that some carbohydrate is tightly bound to collagen but that elastoidin fibers and conventional collagen do not differ greatly in their proportions of carbohydrate.

Although ceratotrichia and conventional collagen fibrils appear to be similar with respect to bound carbohydrate, they differ with respect to their proteins. Sastry and Ramachandran ('65) have summarized their work and earlier studies (Damodaran et al., '56; Gross and Dumsha, '58; Gross et al., '58) showing that elastoidin differs from conventional col. lagen in the following respects: (1) high content of tyrosine (7.15\%); (2) significant amounts of methionine and cystine; (3) relatively low content of hydroxyproline, but an amount equivalent to that of other fish collagens. Although ceratotrichia do not dissolve readily in boiling water, they do yield gelatin after autoclaving (Sastry and Ramachandran, '65). Damodaran et al. ('56) have speculated that the unusually high amounts of cystine and tyrosine in elastoidin might account for its unusual hydrothermal behavior.

Ceratotrichia grow by apposition of small fibrils at their periphery and perhaps also by direct intercalation of tropocollagen molecules. Although chemical evidence, cited above, indicates that carbohydrates and noncollagenous protein may participate in fibrillogenesis of ceratotrichia, electron microscopy has not revealed specific sites which could be interpreted as loci for proteins with special 
binding properties, e.g., proteins containing tyrosine or tryptophane (Sastry and Rama. chandran, '65; Kimura and Kubota, '66, '68). It is possible though that the staining which distinguishes the lamellae in ceratotrichia observed in cross section (fig. 10) could be partly due to interfibrillar non-collagenous protein cementing concentric layers of collagen filaments. We have observed some differences in the staining properties of ceratotrichia and conventional fibrils. Ceratotrichia were especially difficult to stain with uranyl acetate. Staining several hours at $37^{\circ} \mathrm{C}$ was necessary in order to obtain good penetration of uranyl ions. With adequate staining the bands of ceratotrichia were sharply distinct, whereas conventional fibrils in the same preparation might show heavier staining on either side of the $a$ band (figs. 5-7). Few available sites for binding uranyl in ceratotrichia perhaps accounts for the difficulty in staining these fibers. Staining with lead citrate after uranyl acetate did not enhance the electron density of bands in ceratotrichia.

Direction of alignment of the anisometric molecules in collagen fibers, whether in parallel or antiparallel array (Bear, '52), is one of the intriguing problems of fibrillogenesis. We have shown previously (Kemp and Park, '70) that fibrils of opposite polarity might fuse to form a single larger actinotrichium in Tilapia. Constituent fibrils of ceratotrichia, however, appear to have unidirectional polarity throughout their substance. The intermolecular bonding properties which impose this unipolarity are unknown.

As mentioned above, it has been suggested (Fitton Jackson, '68) that polymerization of collagen is probably influenced by the glycosaminoglycans of the ground substance. With respect to teleost actinotrichia, which are homologous to ceratotrichia (Kemp and Park, '70), we speculated that these fibers become large because the rate of production of collagen near the fin margin outstrips the rate for mucopolysaccharides. Such a differential "rate-of-delivery" hypothesis might also apply to the great growth of ceratotrichia relative to conventional collagen fibrils of the shark's fin, although morphological evidence indicates that peritrichial fibroblasts are not different from ordinary connective tissue fibroblasts. If it be true that all fin fibroblasts, i.e., those surrounding actinotrichia or ceratotrichia as well as those of ordinary connective tissue, produce tropocollagen and proteoglycans in the same proportions, then it may be that peritrichial fibroblasts are simply more active in synthesis and secretion of these matrix constituents than are ordinary fibroblasts. They might be more active only at the beginning of the process of polymerization so that a site of enhanced fibrillogenesis would be established in the matrix enclosed by a group of fibroblasts. Thereafter ordinary activity of the peritrichial fibroblasts, the bonding proclivities of small collagen fibrils and associated molecules when closely appressed, and the factors of compression and tension peculiar to the zones of ceratotrichogenesis in the growing fin could account for continued growth of the ceratotrichia. Their bilateral distribution must be the result of equivalent forces operating bilaterally.

\section{ACKNOWLEDGMENTS}

I am grateful to Doctors Perry M. Gilbert, Mote Marine Laboratory, Sarasota, Florida, and I. Kaufman Arenberg, Department of Otolaryngology, University of Wisconsin, Madison, Wisconsin, for donating shark fin tissue. I thank Doctor Wilbur C. Bigelow and his staff at the Scanning Electron Microscopy Laboratory, College of Engineering, University of Michigan, for their assistance in use of the scanning electron microscope. My Research Assistants, Mrs. Marilyn Susko Drnevich, Mrs. Betty J. Christian, Mrs. Sandra Smith Westrin and Richard A. Jacobs have rendered valuable technical assistance during the progress of this investigation. The research was supported by USPHS Grant AM13745 and Grant SOMCR-PP-31 from the University of Michigan Cancer Research Institute.

\section{LITERATURE CITED}

Bailey, A. J., S. P. Robins and G. Balian 1974 Biological significance of the intermolecular crosslinks of collagen. Nature, 251: 105-109.

Bear, R. S. 1952 The structure of collagen fibrils. Adv. Protein Chem., 1: 69-160.

Bouteille, M., and D. C. Pease 1971 The tridimensional structure of native collagenous fibrils, their proteinaceous filaments. J. Ultrastruct. Res., 35: 314-338.

Bouvet, J. 1974 Différenciation et ultrastructure du squelette distal de la nageoire pectorale chez la truite indigène (Salmo trutta fario L). I. Différenciation et ultrastructure des actinotriches. Arch. Anat. Micr., 63: 79-96.

Brohl, E. 1909 Die sogennanten Hornfäden und die Flossenstrahlen der Fische. Jena. Zeit. Naturwiss,, 45. 345-378.

Champetier, G., and E. Fauré-Fremiet 1937 Étude roent- 
génographique de la structure des fibres d'élastoïdine. J. Chim. Phys., 34: 197-204.

Damodaran, M., C. Sivaraman and R. S. Dhavalikar 1956 Amino acid composition of elastoidin. Biochem. J., 62 : 621-625.

Dubey, S. S. 1967 Effects of some salts on glycerinated muscle fibres and elastoidin fibres. Indian J. Biochem., 4: $52-54$.

Engeland, R., and A. Bastian 1938 Contribution à la connaissance de l'èlastoïdine. Compt. Rend. Acad. Sci. Paris, 207: 945.947.

des fibres d'élas.

Chim. Phys., 33: 681-694.

l'élastoïdine. $\mathrm{J}$.

Fitton Jackson, S. 1962 What is the role of connective tissue cells in the formation of the extracellular components of the tissue? In: The Biology of Connective Tissue Cells. The Arthritis and Rheumatism Foundation, New York, pp. 193-196.

1968 The morphogenesis of collagen. In: Treatise on Collagen. Vol. 2. Part B, Biology of Collagen. B. S Gould, ed. Academic Press, New York, pp. 1-66.

Garrault, H., 1936 Dévéloppement des fibres d'élastoïdine (actinotrichia) chez les Salmonides. Arch. Anat. Micr. 32: 105-137.

Geraudie, J. 1977 Initiation of the actinotrichial development in the early fin bud of the fish, Salmo. J. Morph., 151: 353-362.

Goodrich, E. S. 1904 On the dermal fin-rays of fishes living and extinct. Quart. J. Micr. Sci., 47: 465-522.

Gross, J., and B. Dumsha 1958 Elastoidin: a two-component member of the collagen class. Biochim. Biophys. Acta, 28: 268-270.

Gross, J., B. Dumsha and N. Glazer 1958 Comparative biochemistry of collagen. Some amino acids and carbohy drates. Biochim. Biophys. Acta, 30: 293-297.

Gross, J., J. H. Highberger and F. O. Schmitt 1955 Extraction of collagen from connective tissue by neutral salt solutions. Proc. Natl. Acad. Sci. (U.S.A.), 41: 1-7.

Hodge, A. J. 1967 Structure at the electron microscopic level. In: Treatise on Collagen. Vol. I. Chemistry of Collagen. G. N. Ramachandran, ed. Academic Press, New York, pp. 185-205.
Kemp, N. E., and J. H. Park 1970 Regeneration of lepidotrichia and actinotrichia in the tailfin of the teleost Tilapia mossambica. Dev. Biol., 22: 321-342.

Kemp, N. E., and M. A. Susko 1971 Periodic banding pattern of ceratotrichia in the tailfin of the shark Ginglymostoma cirratum. Anat. Rec., 169: 354-355 (Abstract).

Kimura, S., and M. Kubota 1966 Studies on elastoidin. I. Some chemical and physical properties of elastoidin and its components. J. Biochem., 60: 615-620.

1968 Studies on elastoidin. III. Protein components of soluble elastoidin. Bull. Jap. Soc. Sci. Fish., 34: 535-540.

1969 Tyrosine derivatives in a structural protein, elastoidin. J. Biochem., 65: 141-143.

Krukenberg, C. Fr. W. 1886 Über die chemische Beschaffenheit der sog. Hornfäden von Mustelus und uber die Zusammensetzung der keratinösen Hüllen um den Eiern von Scyllium stellare. Mittheil. Zool. Sta. Neapel, 6: 286-296.

Long, D. M., T. S. Bodenheimer, J. F. Hartmann and I. Klatzko 1968 Ultrastructural features of the shark brain. Am. J. Anat., 122: 209-238.

McGavin, S. 1962 The structure of elastoidin in relation to that of tendon collagen. J. Mol. Biol., 5: 275-283.

McGavin, S., and A. S. Pyper 1964 An electron-microscope study of elastoidin. Biochim. Biophys. Acta, 79;600-605.

Olsen, B. R. 1967 Electron microscope studies on collagen. VI. The structure of segment long-spacing aggregates consisting of molecules renatured from isolated $\alpha$. fractions of codfish skin collagen. J. Ultrastruct. Res., 19: 446-473.

Piez, K. A., and J. Gross 1959 The amino acid composition and morphology of some invertebrate and vertebrate col. lagens. Biochim. Biophys. Acta, 34: 24-39.

Pinto, J. S., and J. P. Bentley 1974 The time course of collagen crosslinking. Biochim. Biophys. Acta, 354: 254-263.

Sastry, L., and L. Ramachandran 1965 The protein components of elastoidin. Biochim. Biphys. Acta, 97: 281-287.

Schmidt, W. J. 1924 Über die thermische Verkürzung der Elastoindinfäden der Haie und die begleitenden optischen Erscheinungen. Zeit. Biol., 81: 193-207.

Ysuchiya, Y, and T. Nomura 1953 Chemical nature of the shark's fin fiber. Tohôku J. Agr. Res., 4: 43-53. 
PLATES 
PLATE 1

EXPLANATION OF FIGURES

1 Scanning electron micrograph of cross section of block of tissue excised from anterior margin of anterodorsal fin of a lemon shark, Negaprion brevirostris, showing bilateral rows of ceratotrichia (C) within the dermis. Ordinary dense connective tissue (ct) separates the rows of ceratotrichia and also separates them from the epidermis. Scales (S) are embedded in the dermis. $\times 45$.

2 Scanning electron micrograph showing ceratotrichia $\left(\mathrm{C}_{1}, \mathrm{C}_{2}\right)$ on both sides of central zone of dense connective tissue (ct) in fin of lemon shark. Ceratotrichia appear to be composed of closely packed small fibrils. Variability in their packing pattern is probably due to variations in their displacement during dehydration. $\times 140$.

3 Photomicrograph of cross section of tip of tail fin of a nurse shark Ginglymostoma cirratum, showing bilateral single rows of ceratotrichia (C) embedded in dense connective tissue of dermis. Clear rings around ceratotrichia are shrinkage artifacts. Placoid scales $(\mathbf{S})$ are embedded in the dermis and protrude through the epidermis (E). Hematoxylin and eosin. $\times 185$.

4 Enlargement of central region of a section similar to that of figure 3 , showing bilateral ceratotrichia $\left(C_{1}, C_{2}\right)$ and connective tissue (ct) between them. Flattened peritrichial fibroblasts (pf) surround the ceratotrichia. Hematoxylin and eosin. $\times \mathbf{8 5 0}$. 

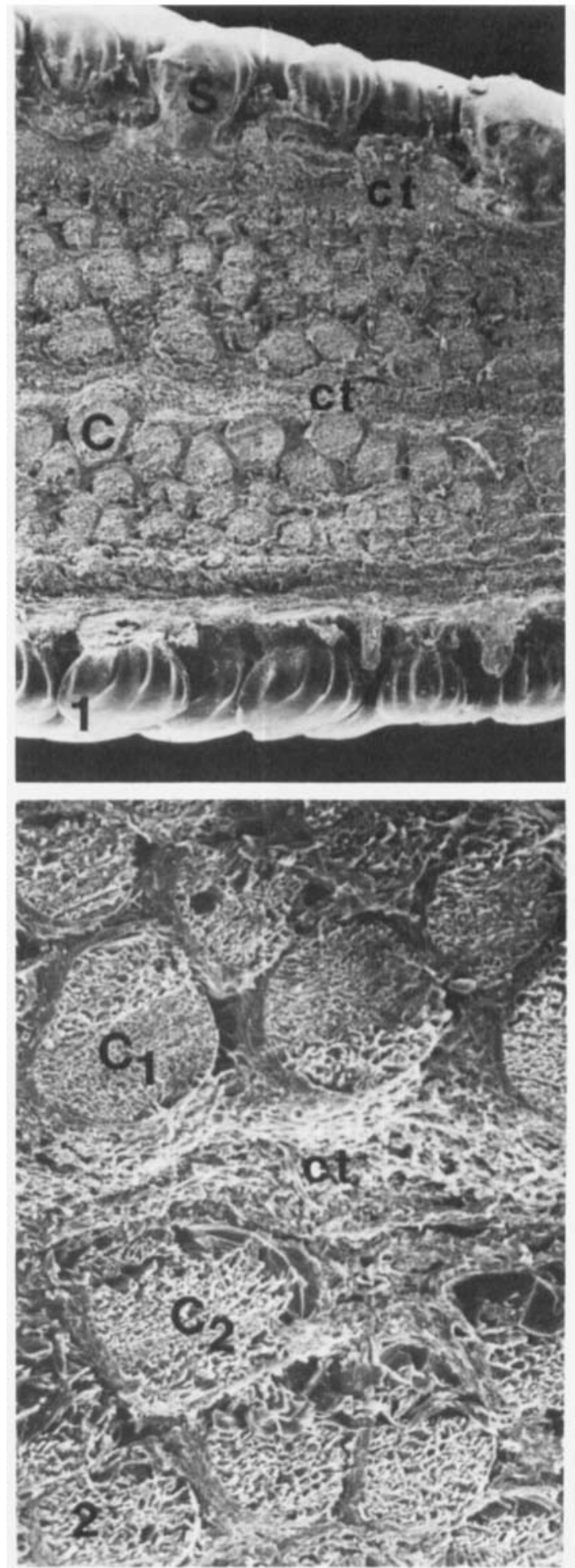
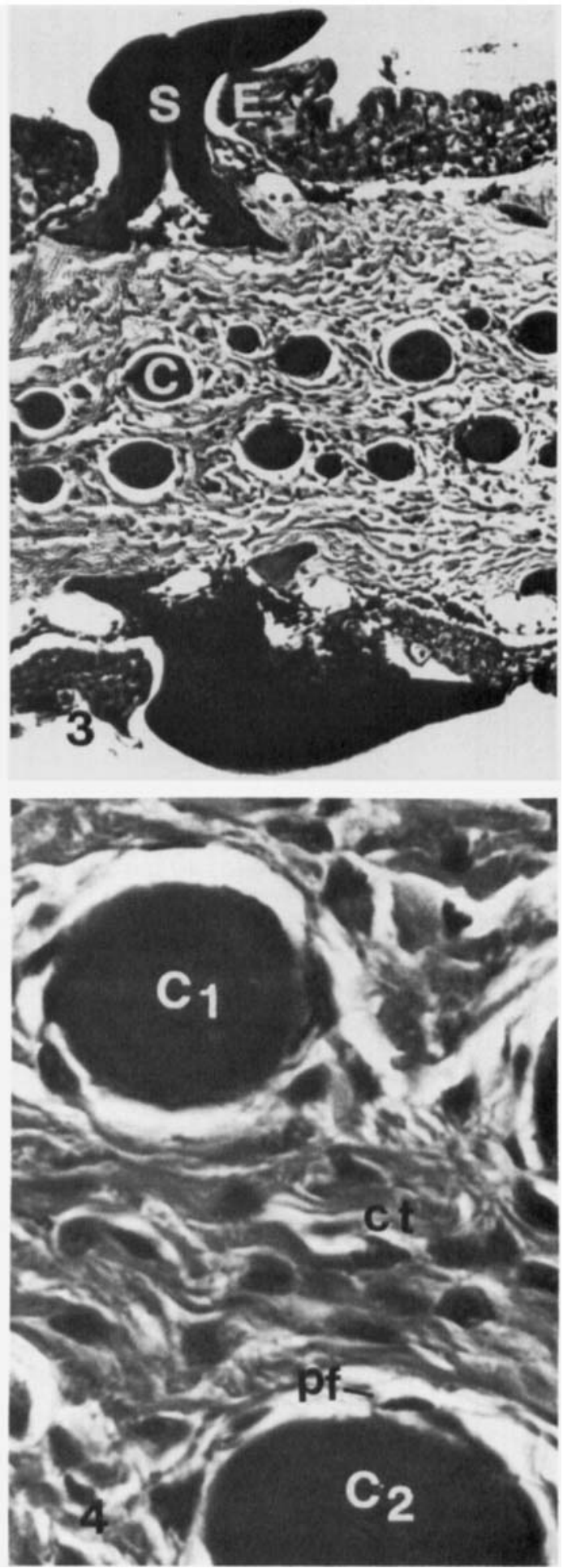


\section{PLATE 2}

\section{EXPLANATION OF FIGURES}

5 Electron micrograph showing banding pattern of ceratotrichium of Ginglymostoma cirratum in longitudinal section. Sections of conventional collagen fibrils (upper left) occupy the matrix adjoining the edge of the ceratotrichium. Fibril at arrow appears to be fusing with the ceratotrichium. Insert at lower left is a magnified view of the ceratotrichial banding pattern, lettered according to Hodge's terminology for collagen fibrils. Periodicity between the prominent $a$ bands is approximately $640 \mathrm{~A}$. Although wider than the $a$ bands, the $d$ bands stain somewhat lighter. Between $a$ and $d$ bands are two $e$ bands. On the opposite side of the $d$ band is the narrow, lighter $c$ band. There are three $b$ bands forming a dark zone between the adjacent $a$ band and the light zone around the $c$ band. $\times 175,000$; insert, $\times 304,685$.

6 Banding pattern in longitudinal sections of conventional collagen fibrils in connective tissue of tailfin of Ginglymostoma at some distance from a ceratotrichium. Direction of anisometry, as indicated by the sequence of bands, is clearly opposite in some fibrils, as, for example, in fibrils $f_{1}$ and $f_{2}$. Bifurcation of fibrils, as at arrow, probably indicates where smaller fibrils have fused to form a larger one. Cross and oblique sections of conventional collagen fibrils at right show light central zones, probably resulting from incomplete fusion of smaller fibrils. $\times 115,500$. 

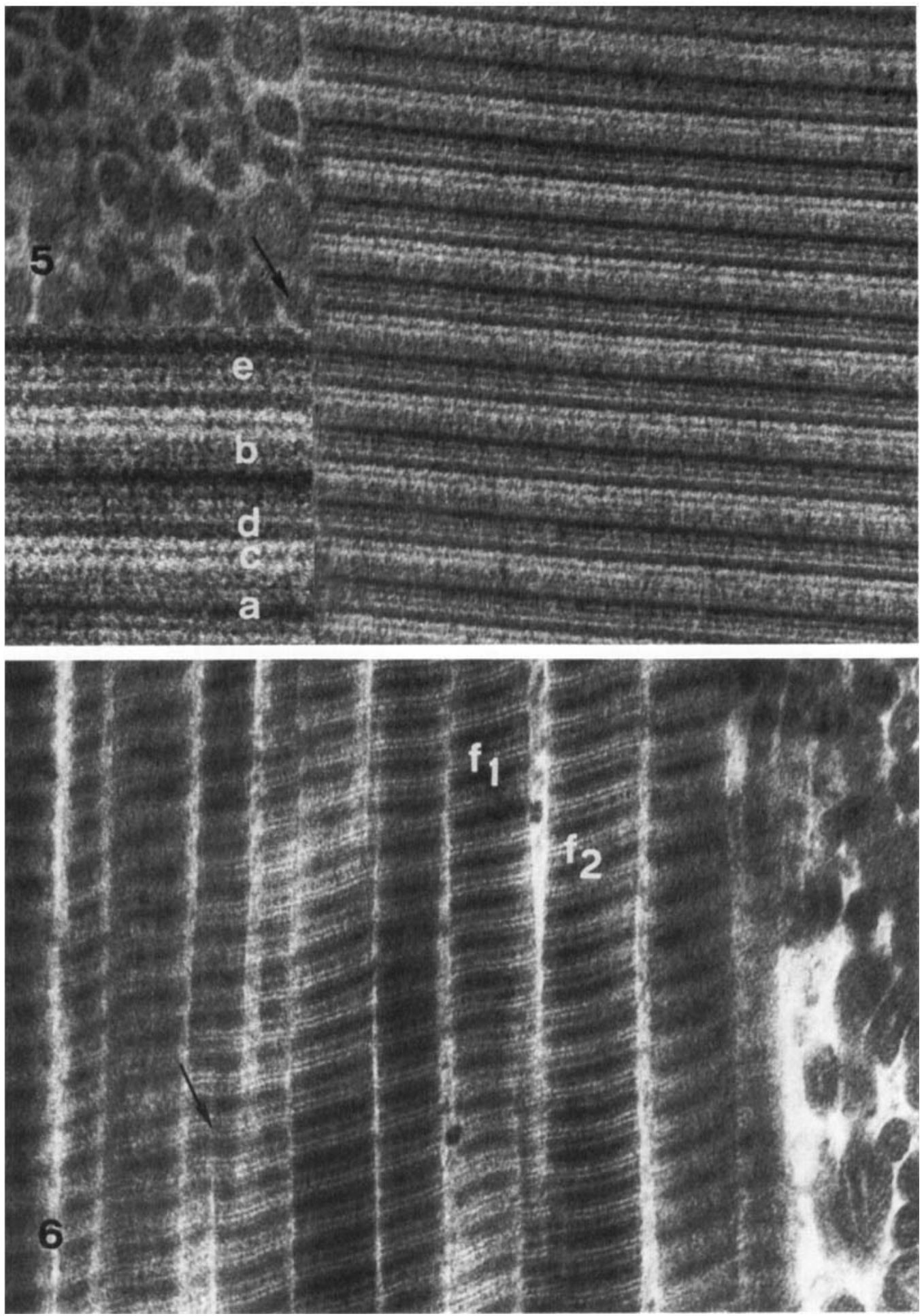


\section{PLATE 3}

\section{EXPLANATION OF FIGURES}

7 Section of lemon shark anterodorsal fin showing periphery of a ceratotrichium (C) sectioned longitudinally, portion of a peritrichial fibroblast ( $\mathrm{PF}$, between arrowheads) in the region of its nucleus $(\mathrm{N})$, and connective tissue matrix $(\mathrm{ctm})$ on either side. Cytoplasm of fibroblast on side away from ceratotrichium shows secretory vesicles $(v)$. Fine collagen fibrils $\left(\mathbf{c f}_{1}\right)$ in the ordinary connective tissue matrix, coursing longitudinally in this view, have about the same diameter $(50-100 \AA)$ as those $\left(c_{2}\right)$ in the fibril assembly zone adja. cent to the ceratotrichium. The banded conventional collagen fibril in the outer matrix (arrow) has the same periodicity as the ceratotrichium. $\times 45,530$.

8 Inner border of peritrichial fibroblast (PF) of lemon shark fin, showing underlying connective tissue matrix (ctm) and edge of a ceratotrichium (C). Fine fibrils in cross section (cf) are heavily stained. Larger fibrils in the surrounding matrix are less heavily stained. $\times 36,585$.

9 Fine collagen fibrils (cf) adjacent to a ceratotrichium (C) in lemon shark fin. Here the fibrils are oriented longitudinally, in the same direction as the ceratotrichium, and are clearly separated by interfibrillar matrix. $\times 60,975$.

10 Inner margin of lemon shark peritrichial fibroblast (PF), underlying connective tissue matrix, and edge of a ceratotrichium (C) sectioned transversely. Fine unbanded collagen fibrils ( $\mathrm{cf}_{1}$ ) of matrix close to the fibroblast, are stained darker than the coarser, banded fibrils $\left(\mathrm{cf}_{2}\right)$ of matrix toward the ceratotrichium. Clusters of fibrils can be seen adhering to the surface of the ceratotrichium (arrow). Within the ceratotrichium there are alternating dark and light layers, apparently resulting from the close packing of constituent collagen fibrils in concentric layers. $\times 34,675$. 


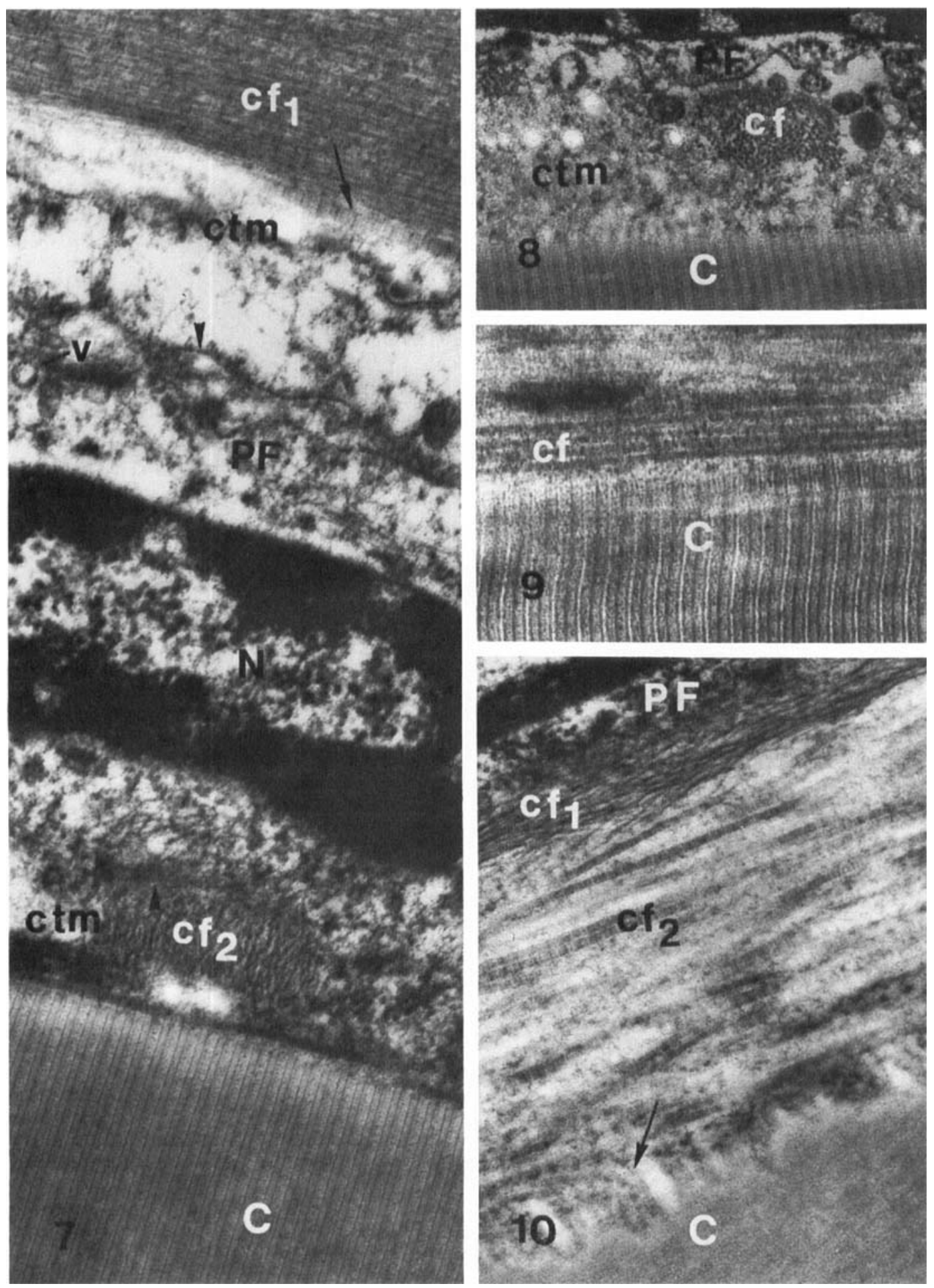


11 Ceratotrichium (C) and adjacent connective tissue in lemon shark fin. A thin process of a peritrichial fibroblast (PF) separates the assembly zone of collagen fibrils beside the ceratotrichium from those on its outer side. In this outer matrix are fine, dense fibrils $\left(\mathrm{cf}_{1}\right)$ and larger, lighter fibrils $\left(\mathrm{cf}_{2}\right)$. The periodicity of the banded conventional fibril (arrow) is the same as that of the ceratotrichium. $v$, secretory vesicles. $\times 43,090$.

12 Periphery of a peritrichial fibroblast (PF) and underlying zone of collagen fibrils adjacent to a developing ceratotrichium $(C)$ in a lemon shark fin. The plane of section is tangential to the irregular surface of the ceratotrichium and shows the transition from conventional fibrils to ceratotrichium along three bands. Fibroblast contains secretory vesicles (v). Fine, unbanded fibrils $\left(\mathrm{cf}_{1}\right)$ have polymerized near the fibroblast, and larger banded fibrils $\left(\mathrm{cf}_{2}\right)$ run longitudinally beside the ceratotrichium. Note that interfibrillar matrix is eliminated as unit fibrils are incorporated in to the ceratotrichium. $\times 27,640$. 

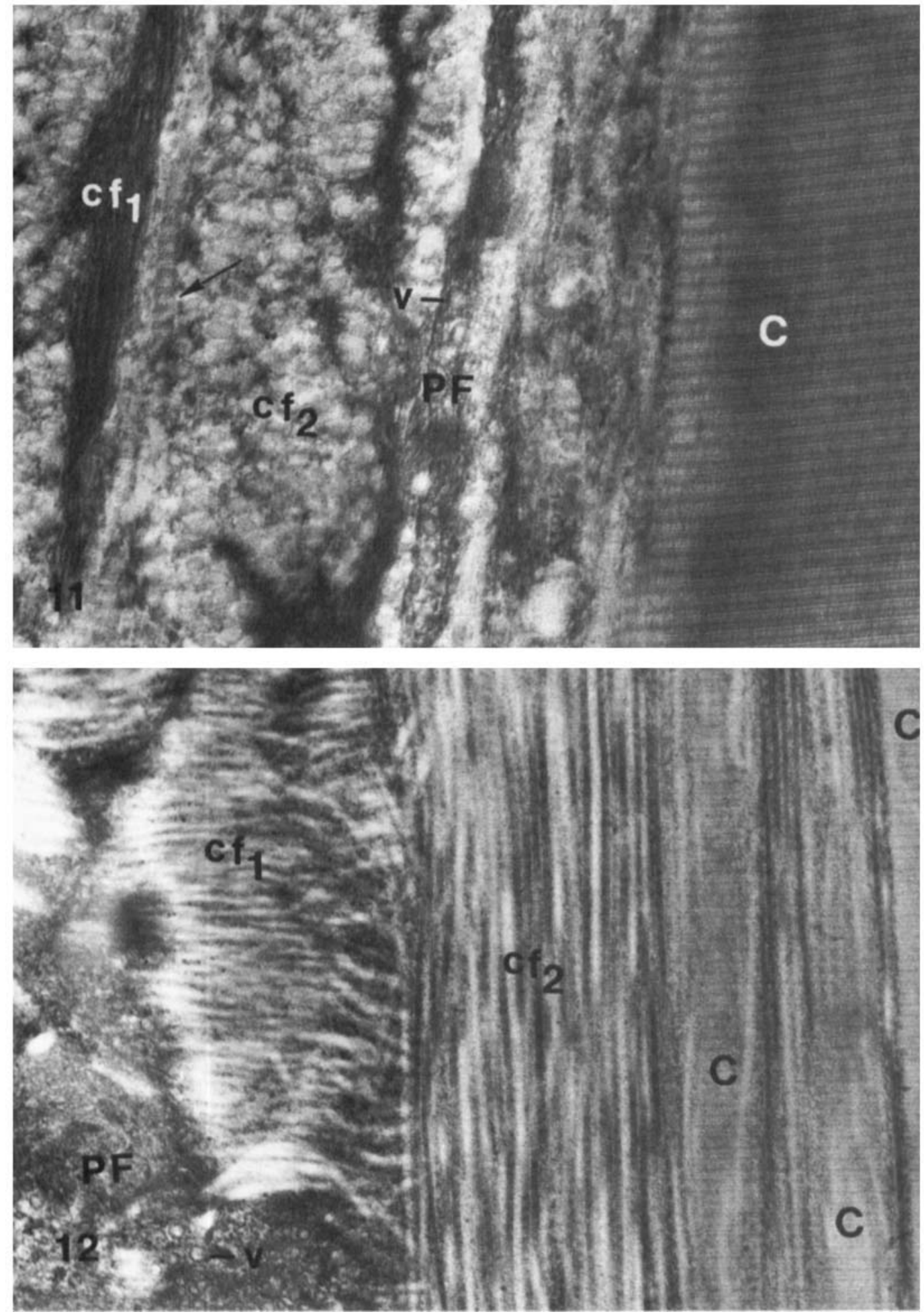
13 Fibroblast (F) showing nucleus (N) and thin layer of cytoplasm, surrounded by matrix of ordinary dense connective tissue in fin of lemon shark. Edge of fibroblast is cut tangentially and shows numerous secretory vesicles (v) close to the surface. Fine, unbanded fibrils $\left(\mathrm{cf}_{1}\right)$ lie close to the cell and coarser, banded fibrils $\left(\mathrm{cf}_{2}\right)$ farther away. $\times 24,490$.

14 Periphery of a fibroblast ( $F$ ) and adjacent collagenous matrix in lemon shark fin. Secretory vesicles $(v)$ are abundant at surface. The matrix shows stages of polymerization of collagen fibrils from fine, unbanded ones $\left(\mathrm{cf}_{1}\right)$ to larger banded ones $\left(\mathrm{cf}_{2}\right)$. Note similarity of fibrillogenesis around this ordinary fibroblast (cf. fig. 13) and around a peritrichial fibroblast (figs. 11, 12). $\times 33,000$. 

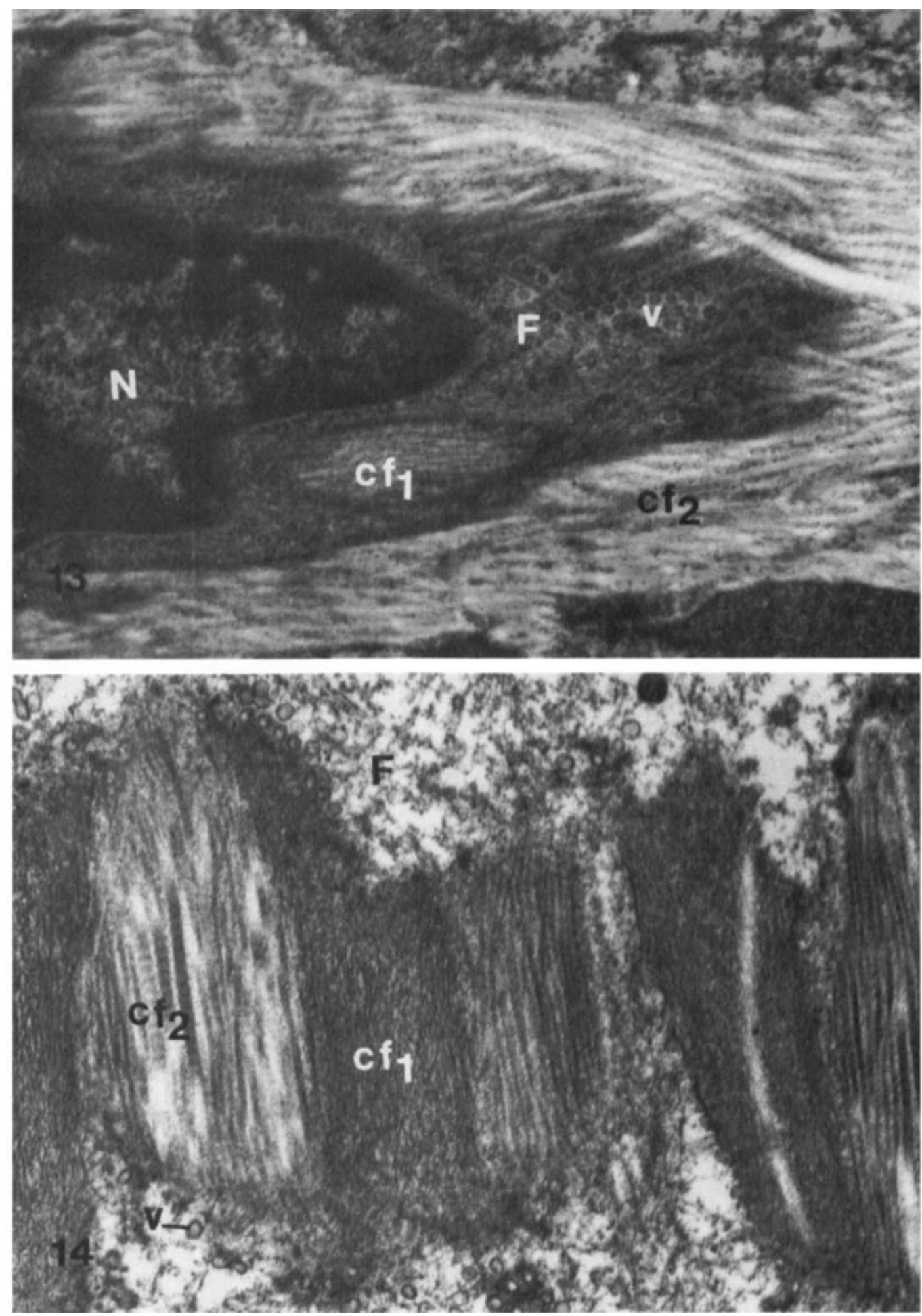